\title{
KEABSAHAN KEPEMILIKAN SILANG SAHAM PERSEROAN TERBATAS DALAM HUKUM INDONESIA
}

\author{
Viendi Hapsari \\ Magister Kenotariatan, Fakultas Hukum, Universitas Narotama Surabaya \\ Email : viendi.jurna12018@gmail.com
}

\begin{abstract}
Limited company stimulates the existence of cross shareholding stocks of the company. Stockholder who invest their capital in limited company is able to establish join venture in other companies in which the company can be in form of private or group. Basically, there are no restrictions which forbid someone to hold stocks in numerous companies. However, rights to hold numerous stocks shall be based on regulations regarding limited company, restriction of monopoly concerning stock in a company, and indisposed business competition.

Author of the present study aims to examine further about the validity of cross shareholding based on regulation of limited company, restrictions of stocks monopoly within companies, and indisposed business competition.

This study uses normative legal research methods by using the statue, conceptual, and case approaches. The legal materials that used as primary sources in the present study are legislation and judgments. Meanwhile, secondary materials that used are judicial books and journals.

The present research shows that cross shareholding of limited company stocks which is caused by the establishment of new stocks in the market is restricted by the regulation of limited company. Meanwhile, cross shareholding of stocks that is caused by the occurrence of stocks transition is not explicitly restricted. The cross shareholding of stocks is justified as breaching the regulation of monopoly and indisposed business competition when someone holds more than 75\% (combine between the stocks of two limited companies)
\end{abstract}

Keywords: Stocks, Cross Shareholding of Stocks, Monopoly

\begin{abstract}
ABSTRAK
Pada perusahan berbentuk Perseroan Terbatas memungkingkan terjadinya kepemilikan silang saham. Pemilik modal yang menanamkan modalnya di suatu perusahaan dapat menanamkan modalnya di Perusahaan lain baik yang berdiri sendiri atau tergabung di dalam group. Pada prinsipnya tidak ada larangan bagi siapapun untuk memiliki saham di setiap perusahaan, namun kepemilikan saham tersebut juga harus memperhatikan pula ketentuan yang diatur di dalam Undang-Undang Perseroan Terbatas dan Undang-Undang Larangan Praktek Monopoli Dan Persaingan Usaha Tidak Sehat.

Penulis dalam penelitian ini ingin menelaah dan menganalisa lebih lanjut tentang keabsahan kepemilikan silang saham menurut UndangUndang Perseroan Terbatas dan kepemilikan silang saham menurut Undang Undang Larangan Praktek Monopoli Dan Persaingan Usaha Tidak Sehat

Metode penelitian yang digunakan adalah penelitian hukum normatif, yaitu penelitian hukum yang dilakukan dengan cara meneliti
\end{abstract}


bahan pustaka atau bahan hukum sekunder sedangkan pendekatan masalah dilakukan dengan menggunakan pendekatan undangundang dan pendekatan konseptual.

Hasil penelitian menunjukkan bahwa kepemilikan silang saham yang timbul sebagai akibat pengeluaran saham baru saja yang dilarang oleh Undang-Undang Perseroan Terbatas, sedangkan untuk silang saham yang diperoleh dari adanya peralihan karena tidak secara eksplisit dikatakan dilarang. Kepemilikan silang saham dikatakan bertentangan dengan Undang-Undang Larangan Praktek Monopoli Dan Persaingan Usaha Tidak Sehat apabila kepemilkan silang saham dari dua Perseroan yang menguasai pasar apabila digabung menjadi satu jumlahnya menguasai lebih $75 \%$ (tujuh puluh lima persen) dari pangsa pasar.

Kata Kunci : Saham, Silang Saham, Monopoli

\section{LATAR BELAKANG}

Rencana Pembangunan Jangka Panjang (RPJP) Tahun 2005-2015 mengarahkan investasi untuk mendukung terwujudnya pertumbuhan ekonomi yang cukup tinggi secara berkelanjutan dan berkualitas dengan mewujudkan iklim investasi yang menarik; mendorong penanaman modal asing bagi peningkatan daya saing perekonomian nasional; serta meningkatkan kapasitas infrastruktur fisik dan pendukung yang memadai. Investasi yang dikembangkan dalam rangka penyelenggaraan demokrasi ekonomi akan dipergunakan sebesarbesarnya untuk pencapaian kemakmuran bagi rakyat. Dengan demikian diharapkan terciptannya iklim investasi yang baik dalam berbagai sektor terutama pada sektor telekomunikasi dan tidak adanya praktek monopoli yang mengakibatkan persaingan usaha tidak sehat.

Hal tersebut dapat dilihat dari izin yang diberikan oleh pemerintah memberikan untuk investasi asing di sektor telekomunikasi yang semula hingga 95\%, namun sekarang jatah tersebut dipangkas menjadi tinggal 49\% saja. Aturan tersebut sudah ada dalam draft final Daftar Negatif Investasi (DNI) yang disusun oleh Departemen
Perdagangan yang isinya membatasi pemodal asing di bidang telekomunikasi tidak boleh lebih dari $49 \%$. Pengusaha asing menguasai yang 50\% lebih di sektor ini harus menguranginya secara bertahap dalam jangka waktu 5 (lima) tahun. Organisasi Perdagangan Dunia (WTO) juga telah sepakat untuk menerima pembatasan kepemilikan asing di perusahaan telekomunikasi hingga $35 \%$. Pembatasan investasi asing dilakukan untuk mencegah adanya monopoli dari pihak asing dan untuk menumbuhkan industry local, selain itu apabila kepemilikan saham asing tidak dibatasi juga akan menimbulkan kepemilikan saham saling silang. Adanya kepemilikan saham saling silang dilarang didalam dunia usaha.

Pengaturan mengenai kepemilikan saham dalam Perseroan Terbatas di Indonesia tunduk pada ketentuan Undang-Undang Nomor 40 Tahun 2007 Tentang Perseroan Terbatas (selanjutnya ditulis Undang-Undang Perseroan Terbatas). Selain itu harus diperhatikan pula ketentuan yang diatur dalam Undang-Undang Nomor 5 Tahun 1999 Tentang Larangan Praktek Monopoli Dan Persaingan Usaha Tidak Sehat (selanjutnya ditulis Undang-Undang Larangan Praktek Monopoli Dan Persaingan Usaha Tidak Sehat). 
Pada prinsipnya tidak ada larangan bagi siapapun untuk memiliki saham di setiap perusahaan. Adanya larangan mengenai kepemilikan saham saling silang dianggap tidak sesuai dengan perkembangan teknologi karena industry telekomunika Indonesia masih membutuhkan modal besar yang hanya bisa didapat dari investor asing, selain itu jika seorang investor memiliki beberapa perusahaan sekaligus dianggap sebagai hasil sinergi dan merupakan strategi industry untuk bertahan dalam kancah persaingan global.

\section{RUMUSAN MASALAH}

1) Bagaimana keabsahan kepemilikan silang saham menurut UndangUndang Perseroan Terbatas?

2) Bagaimana kepemilikan silang saham menurut Undang Undang Larangan Praktek Monopoli Dan Persaingan Usaha Tidak Sehat?

\section{METODE PENELITIAN}

Metode yang digunakan dalam penelitian ini adalah metode penelitian yuridis normatif yang menekankan pada norma-norma hukum dengan menganalisa peraturan perundangundangan terkait. Dalam Penelitian ini peneliti menggunakan dua metode pendekatan masalah yaitu : 1) Statute Approach, pendekatan dengan menelaah semua peraturan perundang-undangan yang bersangkut paut dengan permasalahan (isu hukum) yang sedang dihadapi. 2) Conseptual Approach, yaitu pendekatan yang beranjak dari pandangan-pandangan dan doktrindoktrin yang berkembang di dalam ilmu hukum. $^{1}$

1 Peter Mahmud Marzuki,Penelitian Hukum, Kencana Prenada Media, Jakarta, 2010, hal. 95-97

\section{PEMBAHASAN}

\section{Keabsahan Kepemilikan Silang Saham Menurut Undang-Undang Perseroan Terbatas}

Semua perbuatan hukum yang dilakukan oleh perseroan terbatas akan selalu dipertanggungkan dengan harta perkumpulan modal yang kemudian akan tampak dalam keadaan harta kekayaan perseroan tersebut baik pengurangan atau pertambahannya. Modal dalam perseroan selanjutnya dibagi-bagi kedalam saham-saham yang menunjukkan besarnya bagian penyertaan dari setiap penyetor modal kedalam perseroan. Secara umum struktur permodalan dalam perseroan terbatas terdiri dari modal dasar, modal dikeluarkan/ditempatkan dan modal disetor.

Berbicara tentang saham, UUPT hanya menyebutkan bahwa modal dasar perseroan terdiri atas seluruh nilai nominal saham dan saham merupakan benda bergerak yang memberikan hak kepemilikan kepada pemiliknya. Namun jika dicermati secara seksama, maka penjabaran mengenai pengertian saham tidak ditemukan didalam UUPT. Dengan demikian perlu kiranya ditelusuri beberapa literatur tambahan untuk memperoleh pengertian saham tersebut. $^{2}$

Dalam Kamus Besar Bahasa Indonesia $(\mathrm{KBBI})^{3}$ dilihat dari sudut pandang ekonomis saham berarti surat bukti bagian modal perseroan terbatas yang memberi hak atas deviden dan lain-lain menurut besar kecilnya modal

2 Juliana Citra, "Kajian Hukum Tentang

Kepemilikan Silang Saham Menurut Undang-Undang Perseroan Terbatas Nomor 40 Tahun 2007", Tesis, Sekolah Pasca Sarjana, Universitas Sumatra Utara, Medan, 2009, hal. 31-35 
yang disetor; saham adalah hak yang dimiliki orang (pemegang saham) terhadap perusahaan berkat penyerahan bagian modal sehingga dianggap berbagi di pemilikan dan pengawasan.

Dalam Kamus Istilah Hukum Fockema Andreae ${ }^{4}$ dikemukakan, aandeel (Belanda), saham (Indonesia) adalah hak pada sebagian modal suatu perseroan; andil dalam perseroan atau perusahaan, bagian-bagian modal pada perusahaan yang telah dibagi-bagi pada akte pendirian.

Sementara itu dalam Kamus Khusus Pasar Uang dan Modal ${ }^{5}$ dijelaskan, saham adalah surat bukti pemilikan bagian modal perseroan terbatas yang memberi hak atas deviden dan lain-lain menurut besar kecilnya modal yang disetor. Oleh John Downs dan Jordan Elliot Goodman menyebutkan :6 "Saham (share) adalah unit kepemilikan ekuitas dalam suatu perseroan. Kepemilikan ini diwakili oleh suatu sertifikat saham yang menyebutkan nama perusahaan dan nama pemilik saham. Banyaknya saham yang dikuasakan kepada perseroan untuk diterbitkan dirinci dalam anggaran dasar perseroan. Biasanya

3 Departemen Pendidikan Nasional, Kamus Besar Bahasa Indonesia, Balai Pustaka, Jakarta, 2000, hal.977.

4 H.Boerhanoedin St.Batuah, dkk., Kamus Istilah Hukum Fockema Andreae BelandaIndonesia, Binacipta, Bandung, 1983, hal.2.

5 Departemen Keuangan RI-Badan Pelaksana Pasar Modal, Kamus Khusus Pasar Modal dan Uang, Tanpa Penerbit, Jakarta, 1974, hal.49.

6 John Downs dan Jordan Elliot Goodman, Kamus Istilah Keuangan dan Investasi, Elex Media Komputindo, Jakarta, 1994, hal.525. perseroan tidak menerbitkan semua saham yang diterbitkan."

Sehubungan dengan UUPT yang menekankan pentingnya penyetoran modal perseroan, Gunawan Widjaja kemudian menyebutkan : "saham adalah bukti telah dilakukannya penyetoran penuh modal yang diambil bagian oleh para pemegang saham perseroan terbatas. Yang juga berarti saham menunjukkan bagian kepemilikan bersama dari seluruh pemegang saham dalam suatu perseroan terbatas".

Pada dasarnya hak-hak atas saham sangat tergantung pada jenis saham yang dimiliki. Sebagaimana disebutkan didalam klasifikasi saham yang menyebutkan dapat diterbitkanya beberapa jenis saham dari klasifikasi yang berbeda, hal ini berfungsi sebagai daya tarik bagi pemilik modal agar bersedia menanamkan modal dalam suatu perseroan terbatas yang menerbitkan saham. Dan bagi para pendiri yang menghendaki eksistensinya diakui sebagai pendiri perusahaan, karenanya bagi pendiri diberikan hak-hak khusus dalam kepemilikan perusahaan. ${ }^{8}$

Berbicara tentang bagaimana terjadinya kepemilikan silang saham, pertama-tama perlu diketahui bagaimana hak milik atas saham berpindah dari satu orangkepada orang lain dan dari perseroan yang satu berpindah kepada perseroan yang lain.

Pada dasarnya ketentuan yang mengatur tentang saham adalah sejalan dengan ketentuan Pasal 511 angka 4 KUHPerdata yang menyatakan bahwa yang dianggap sebagai kebendaan

7 Gunawan Widjaja, Hak Individu dan Kolektif Para Pemegang Saham, Forum Sahabat, Jakarta, 2008, hal.33.

\section{Ibid}


bergerak karena ditentukan undangundang adalah juga termasuk didalamnya sero-sero atau andil-andil dalam persekutuan perdagangan uang, persekutuan dagang atau persekutuan perusahaan, sekalipun benda-benda persekutuan yang bersangkutan dan perusahaan itu merupakan kebendaan tidak bergerak. Ini berarti saham-saham atau sero-sero atau andil-andil adalah merupakan kebendaan bergerak, dan karenanya secara umum tunduk pada hal-hal yang mengatur tentang kebendaan bergerak. Sebagaimana terjadinya peralihan hak milik atas benda pada umumnya demikian pula peralihan hak atas saham yakni dapat melalui:

1. Perjanjian, misalnya jual beli, tukar menukar, hibah;

2. Undang-undang, misalnya dalam hal terjadi pewarisan;

3. Karena putusan hakim yang berkekuatan hukum tetap atau yang dipersamakan dengan itu, seperti halnya melalui pelelangan.

Sebagaimana dijelaskan pada bab sebelumnya tentang asas hak kebendaan saham, maka saham merupakan benda bergerak yang dapat beralih dan dialihkan serta dapat dijadikan jaminan utang. Namun karena saham adalah bukti penyertaan pemegang saham dalam perseroan dan sekaligus bukti pemilikan harta bersama yang terikat dalam perseroan terbatas, yang keberadaannya melalui mekanisme pendaftaran di Menteri Hukum dan HAM. Maka peralihan hak milik atas saham tentunya harus dibuat dalam bentuk akta (otentik atau dibawah tangan)111, akta pemindahan hak atas saham tersebut wajib dicatatkan kedalam daftar pemegang saham atau daftar khusus, dan wajib melakukan pemberitahuan terhadap perubahan susunan pemegang saham pada Menteri Hukum dan HAM. Sedangkan untuk pemindahan hak atas saham yang diperdagangkan di Pasar Modal disesuaikan dengan Undang-Undang yang mengatur tentang Pasar Modal.

Kepemilikan silang menurut UUPT adalah keadaan dimana perseroan yang satu memiliki saham yang dikeluarkan oleh perseroan lain, yang sahamnya baik secara langsung atau tidak telah dimiliki oleh perseroan. Ketentuan ini diatur oleh Penjelasan Pasal 36 UUPT. Pasal 36 UUPT sendiri mengatur mengenai masalah pengeluaran saham dengan tujuan pengumpulan modal, karenanya penjelasan tentang kepemilikan silang secara secara langsung bersangkutan dengan upaya perusahaan mengumpulkan modal. Jadi, sehubungan dengan perusahaan mengupayakan adanya pengeluaran saham untuk mengumpulkan modal, maka pihak pembeli haruslah pihak luar perusahaan, karena perusahaan tidak boleh mengeluarkan saham untuk dimiliki sendiri. Dan kepemilikan silang sendiri terjadi jika perusahaan yang sudah memiliki saham yang dikeluarkan oleh perusahaan lain, jika perusahaan lain tersebut kemudian mengeluarkan saham untuk pengumuman modal lagi, maka tidak boleh dibeli, jika dibeli maka terjadilah kepemilikan silang. ${ }^{9}$

Pengaturan mengenai kepemilikan saham disebutkan dalam Pasal 36 UUPT:

(1) Perseroan dilarang mengeluarkan saham baik untuk dimiliki sendiri maupun dimiliki oleh Perseroan lain, yang sahamnya secara langsung atau tidak langsung telah dimiliki oleh Perseroan.

(2) Ketentuan larangan kepemilikan saham sebagaimana dimaksud pada ayat (1) tidak berlaku terhadap kepemilika saham yang diperoleh

9 Juliana Citra, Op.Cit., hal. 71 
berdasarkan peralihan karena hukum, hibah, atau hibah wasiat.

(3) Saham yang diperoleh berdasarkan ketentuan sebagaimana dimaksud pada ayat (2), dalam jangka waktu 1 (satu) tahun setelah tanggal perolehan harus dialihkan kepada pihak lain yang tidak dilarang memiliki saham dalam Perseroan.

(4) Dalam hal Perseroan lain sebagaimana dimaksud pada ayat (1) merupakan perusahaan efek, berlaku ketentuan peraturan perundang-undangan di bidang pasar modal.

Pada Penjelasan UUPT Pasal 36 ayat (1) disebutkan pula Pada prinsipnya, pengeluaran saham adalah suatu upaya pengumpulan modal, maka kewajiban penyetoran atas saham seharusnya dibebankan kepada pihak lain. Demi kepastian, Pasal ini menentukan bahwa Perseroan tidak boleh mengeluarkan saham untuk dimiliki sendiri. Larangan tersebut termasuk juga larangan kepemilikan silang (cross holding) yang terjadi apabila Perseroan memiliki saham yang dikeluarkan oleh Perseroan lain yang memiliki saham Perseroan tersebut, baik secara langsung maupun tidak langsung.

Pengertian kepemilikan silang secara langsung adalah apabila Perseroan pertama memiliki saham pada Perseroan kedua tanpa melalui kepemilikan pada satu "Perseroan antara" atau lebih dan sebaliknya Perseroan kedua memiliki saham pada Perseroan Pertama. Selanjutnya dalam Penjelasan Pasal 36 ayat (2) UUPT dapat diketahui bahwa kepemilikan sama yang mengakibatkan pemilikan saham oleh Perseroan sendiri atau pemilikan saham secara kepemilikan silang tidak dilarang, jika pemilikan saham tersebut diperoleh berdasarkan peralihan kerena hukum, hibah, atau wasiat oleh karena dalam hal ini tidak ada pengeluaran saham yang memerlukan setoran dana dari pihak lain, sehingga tidak melanggar ketentuan larangan sebagaimana dimaksud pada ayat (1).

Menurut Muria Bonita dan Guntur Putro Jati, UUPT mengatur mengenai larangan kepemilikan saham silang, baik secara langsung maupun secara tidak langsung antar perusahaan. Kepemilikan saham silang tersebut terjadi apabila misalnya, perusahaan A memiliki saham perusahaan $B$, dan perusahaan $B$ justru memiliki saham di perusahaan A. Apabila hal tersebut terjadi, kepemilikan saham tersebut harus dijual ke pihak lain yang tidak terafiliasi. ${ }^{10}$

Sehubungan dengan penjelasan Pasal 36 ayat (2) UUPT, kepemilikan saham perseroan oleh anak perusahaan dan atau cucu perusahaan dan seterusnya yang timbul sebagai akibat peralihan karena hukum dan atau jual beli, hibah dan wasiat tidak secara eksplisit dikatakan dilarang, namun dengan konsekuensi hukum bahwa terjadinya kepemilikan silang tidak boleh dibiarkan permanen. ${ }^{11}$

Dari apa yang telah diuraikan di atas dapat diketahui bahwa dalam UUPT larangan kepemilikan silang

10 Muria Bonita dan Guntur Putro Jati, "Cermati UU PT Baru, Banyak Aturan Krusial" dalam Rita Tri Agustina, "Tinjauan Yuridis Larangan Kepemilikan Saham Silang (Share Cross Ownership) Antar Perusahaan Telekomunikasi Berdasarkan Undang-Undang Nomor 5 Tahun 1999 Tentang Larangan Praktek Monopoli Dan Persaingan Usaha Tidak Sehat", Tesis, Fakultas Hukum, Universitas Sebelas Maret, Surakarta, 2008, hal. 87.

11 Gunawan Widjaja, Op.Cit., hal.49. 
adalah larangan kepemilikan yang timbul sebagai akibat pengeluaran saham baru untuk dimiliki anak perusahaan dan atau cucu perusahaan dan seterusnya. Dengan demikian berarti dari tiga jenis kepemilikan saham perseroan terbatas oleh anak perusahaan hanya kepemilikan saham yang timbul sebagai akibat pengeluaran saham baru saja yang dilarang dengan tegas.

\section{Kepemilikan Silang Saham Menurut Undang Undang Larangan Praktek Monopoli Dan Persaingan Usaha Tidak Sehat}

Untuk dapat lebih memahami substansi hukum persaingan usaha di Indonesia, hal pertama yang perlu dilakukan adalah dengan memahami apa yang dimaksud dengan "persaingan", dan "monopoli". Persaingan (competition) dalam bahasa Inggris didefinisikan sebagai "rivalry between two or more businesses striving for the same customer or market." " Dari definisi tersebut dapat dilihat bahwa dalam setiap persaingan akan terdapat dua unsur :

a. ada dua usaha atau lebih yang terlibat dalam upaya saling mengungguli;

b. dilakukan dalam satu pasar yang sama.

Pengertian "persaingan" sebagaimana dikemukakan di depan merupakan definisi "persaingan" di

12 The Editors of Second College Edition, The American Heritage Dictionary, 2nd ed.,

Houghton Mifflin Company, Boston, 1982, hal . 301. dalam Maria Cesilia Hapsari, "Analisis

Yuridis Terhadap Penerapan Pasal 50 Huruf A Undang-Undang Nomor 5 Tahun 1999 Tentang Larangan Praktek Monopoli Dan Persaingan Usaha Tidak Sehat (Studi Kasus Putusan Mahkamah Agung Nomor 03/K/KPPU/2006)", Tesis, Universitas Indonesia, Fakultas Hukum, Program Studi Ilmu Hukum, Kekhususan Hukum Ekonomi, Jakarta, Juli 2010, hal. 26. bidang ekonomi. Dalam UU 5/1999, tidak didefinisikan secara tegas mengenai "persaingan". Undangundang ini hanya memberikan pengertian mengenai "persaingan usaha tidak sehat" yang disebutkan dalam Pasal 1 angka 6 UU 5/1999, yaitu : "Persaingan antar pelaku usaha dalam menjalankan kegiatan produksi dan atau pemasaran barang dan atau jasa yang dilakukan dengan cara tidak jujur atau melawan hukum atau menghambat persaingan usaha."

Menurut Arie Siswanto, secara sederhana persaingan usaha (bussiness competition) dapat didefinisikan sebagai persaingan usaha antara para penjual di dalam merebut pembeli dan pangsa pasar. ${ }^{13}$ Masih menurut Arie Siswanto, Hukum Persaingan Usaha (bussiness competition law) berisi ketentuanketentuan substansial tentang tindakantindakan yang dilarang (beserta konsekuensi hukum yang timbul) dan ketentuan-ketentuan prosedural mengenai penegakan hukum persaingan. ${ }^{14}$

Berdasarkan pengertian di atas dapat disimpulkan bahwa Hukum Persaingan Usaha merupakan suatu ketentuan-ketentuan yang mengatur mengenai penegakan hukum dalam persaingan usaha, yaitu persaingan antara para penjual di dalam merebut pembeli dan pangsa pasar.

Tujuan dari adanya norma yang mengatur tentang persaingan usaha secara umum adalah :

1. Pencegahan atau peniadaan
monopoli

13 Arie Siswanto, Hukum Persaingan Usaha, Ghalia Indonesia, Jakarta, 2002, hal. 14

14 Ibid, hal.30 
2. Menjamin terjadinya persaingan yang sehat

3. Melarang persaingan yang tidak jujur.

Makna persaingan menjadi begitu penting karena dengan adanya persaingan, pelaku usaha akan berlomba-lomba untuk meningkatkan kualitas dari barang dan atau jasa (produk) yang dihasilkannya. Keadaan ini akan menguntungkan konsumen karena mereka akan memiliki beragam pilihan dalam mengonsumsi produk dengan harga yang pantas dan kualitas yang baik.

Larangan pemilikan saham mayoritas dan atau pendirian beberapa perusahaan yang memiliki kegiatan usaha yang sama yang diatur dalam UU Pasal 27 UU 5/1999 menyatakan mengenai larangan pemilikan saham mayoritas pada beberapa perusahaan sejenis yang melakukan kegiatan usaha dalam bidang yang sama pada pasar bersangkutan yang sama.

Namun tidak hanya diatur mengenai pemilikan sahamnya tetapi juga megenai mendirikan beberapa perusahaan yang memiliki kegiatan usaha yang sama pada pasar bersangkutan yang sama. Oleh karena itu, maka terkait dengan pembahasan Pasal 27 UU 5/1999 akan terdapat 2 pembahasan yaitu:

a. Pemilikan saham mayoritas

b. Pendirian beberapa perusahaan

Ketentuan Pasal 27 UU 5/1999 menyebutkan : "Pelaku usaha dilarang memiliki saham mayoritas pada beberapa perusahaan sejenis yang melakukan kegiatan usaha dalam bidang yang sama pada pasar bersangkutan yang sama, atau mendirikan beberapa perusahaan yang memiliki kegiatan usaha yang sama pada pasar bersangkutan yang sama, apabila kepemilikan tersebut mengakibatkan: a. satu pelaku usaha atau satu kelompok usaha menguasai lebih dari 50\% (lima puluh persen) pangsa pasar satu jenis barang atau jasa tertentu;

b. dua atau tiga pelaku usaha atau kelompok pelaku usaha menguasai lebih dari 75 (tujuh puluh lima persen) pangsa pasar satu jenis barang atau jasa tertentu."

Dari ketentuan Pasal 27 tersebut ada beberapa unsur yang didefinisikan yaitu unsur-unsur sebagai berikut:

1. Unsur Pelaku Usaha

Pengertian mengenai definisi Pelaku Usaha telah didefinisikan dalam ketentuan Pasal 1 angka 5 dari UU 5/1999 yaitu setiap orang perorangan atau badan usaha, baik yang berbentuk badan hukum atau bukan badan hukum yang didirikan dan berkedudukan atau melakukan kegiatan dalam wilayah hukum negara Republik Indonesia, baik sendiri maupun bersama-sama melalui perjanjian, menyelenggarakan berbagai kegiatan usaha dalam bidang ekonomi.

2. Unsur Saham Mayoritas

Kepemilikan saham mayoritas adalah merupakan bentuk penguasaan terhadap bagian modal perusahaan yang berakibat bahwa pemegang saham yang bersangkutan memegang kendali terhadap manajemen, penentuan arah, strategi, dan kebijakan perusahaan termasuk tapi tidak terbatas pada kebijakan pengambilan tindakan korporasi (corporate actions), penentuan direksi/komisaris, pelaksanaan hak veto, akses terhadap informasi sensitif (private information), pembagian keuntungan, penggabungan, peleburan, dan atau pengambilalihan;

3. Unsur Perusahaan 
Definisi mengenai Perusahaan didapat dari berbagai sunber, namun secara umum dapat didefinisikan setiap bentuk usaha yang menjalankan setiap jenis usaha yang bersifat tetap dan terus menerus dan yang didirikan, bekerja serta berkedudukan dalam wilayah Negara Republik Indonesia, untuk tujuan memperoleh keuntungan dan atau laba, termasuk perusahaanperusahaan yang dimiliki atau bernaung di bawah lembaga-lembaga sosial.

Terdapat perbedaan terkait dengan definisi perusahaan, dimana Sejalan dengan ketentuan Pasal 27, pengertian perusahaan meliputi segala jenis perusahaan baik yang berbadan hukum dan mengenal konsep kepemilikan saham, yaitu perseroan terbatas, maupun yang tidak berbadan hukum. ${ }^{15}$

4. Unsur Pasar Bersangkutan

Definisi mengenai Pasar bersangkutan, telah diatur menurut ketentuan pasal 1 angka 10 dari UU No.5/1999 yaitu pasar yang berkaitan dengan jangkauan atau daerah pemasaran tertentu oleh pelaku usaha atas barang dan atau jasa yang sama atau sejenis atau substitusi dari barang dan atau jasa tersebut.

5. Unsur Mendirikan Beberapa Perusahaan

15 Indar Sri Bulan, “Tanggung Jawab Pribadi Pemegang Saham Berdasarkan

Kepemilikan Sahamnya Menurut Ketentuan Pasal 27 Undang-Undang Nomor 5 Tahun 1999 Tentang Larangan Praktek Monopoli Dan Persaingan Usaha Tidak Sehat Juncto Undang-Undang Nomor 40 Tahun 2007

Tentang Perseroan Terbatas", Tesis, Fakultas Hukum, Program Studi Magister Kenotariatan, Universitas Indonesia, Depok, Juli 2010, hal. 26
Mendirikan beberapa perusahaan berarti membentuk lebih dari satu perusahaan.

6. Unsur Pangsa Pasar

Pangsa pasar, menurut ketentuan pasal 1 angka 13 dari UU No.5/1999 adalah persentase nilai jual atau beli barang atau jasa tertentu yang dikuasai oleh pelaku usaha pada pasar bersangkutan dalam tahun kalender tertentu.

Dasar dilakukan pelarangan terhadap kepemilikan saham mayoritas oleh suatu pelaku usaha atau satu kelompok usaha adalah berdasarkan ketentuan Pasal 27 UU 5/1999, adalah didasarkan pada hal sebagai berikut:

1. Pelaku usaha memiliki saham mayoritas pada dua atau lebih perusahaan/perseroan yang merupakan perusahaan sejenis;

2. Dua atau lebih perusahaan tersebut melakukan kegiatan usaha pada pasar bersangkutan yang sama

3. Dalam anggaran dasar perseroan, memberikan kewenangan yang lebih besar kepada pelaku usaha tersebut untuk melakukan pengendalian atas perseroan; dan

4. Dengan batasan kepemilikan pelaku usaha pada dua atau lebih perusahaan tersebut mengakibatkan satu pelaku usaha atau satu kelompok pelaku usaha menguasai pangsa pasar sebesar 50\% atas suatu barang/jasa atau menguasai pangsa pasar sebesar $75 \%$ atas suatu barang/jasa.

Secara umum tidak ada larangan suatu pelaku usaha atau satu kelompok pelaku usaha memiliki saham dalam beberapa perusahaan, yang dilarang adalah bentuk penguasaan terhadap modal perusahaan yang berakibat pada pemegang saham tersebut dapat memegang kendali terhadap manajemen, penentuan arah, strategi, dan kebijakan perusahaan, termasuk tapi tidak terbatas pada penentuan 
direksi/komisaris, penentuan hak veto, akses terhadap informasi sensitif (private information), pembagian keuntungan dan tindakan korporasi (corporate actions) termasuk tetapi tidak terbatas pada penggabungan, peleburan, pengambilalihan, pemisahan, divestasi, investasi, pencatatan saham pada bursa, privatisasi.

Tidak cukup sampai hanya dapat berakibat pada memegang kendali terhadap hal tersebut diatas saja, akan dilakukan langkah lain berupa 1 . pembuktian bahwa penguasaan dan pengendalian pada beberapa perusahaan tersebut adalah menjalankan kegiatan usaha yang sama serta berada pada pasar bersangkutan yang sama pula.

Ketentuan dalam Pasal 1 angka 10 dari UU 5/1999 diatur definisi dari pasar bersangkutan yaitu pasar yang berkaitan dengan jangkauan atau daerah pemasaran tertentu oleh pelaku usaha atas barang dan atau jasa yang sama atau sejenis atau substitusi dari barang dan atau jasa tersebut. Pembuktian penguasaan saham juga akan mengukur tingkat penguasaan pada pasar bersangkutan.

Pengertian dari kendali yang dimaksud adalah baik kendali dengan memiliki proporsi jumlah saham secara 2 . kumulatif lebih besar yang dimiliki oleh satu pelaku usaha atau kelompok pelaku usaha dibandingkan dengan jumlah saham yang dimiliki oleh pelaku usaha atau kelompok pelaku usaha lain atas badan usaha yang sama. Misalkan suatu perusahaan dimiliki oleh empat pelaku usaha dengan komposisi kepemilikan $35 \%$, 25\%, dan $25 \%$ dan $15 \%$, maka saham mayoritas dalam hal ini adalah 3 kepemilikan 35\%. Pemilikan saham mayoritas hanya pada satu perusahaan saja, tidak dapat dikenakan ketentuan pasal 27 UU Nomor 5 Tahun 1999 karena pengaturan dalam pasal tersebut adalah kepemilikan saham mayoritas pada dua atau lebih perusahaan. Selain itu dikenal juga kendali bentuk lain yaitu walaupun memiliki saham tidak dalam jumlah terbanyak tetapi cukup untuk pengambilan keputusan strategis dalam rapat umum pemegang saham.

Untuk melihat apakah suatu kepemilikan saham dan atau pendirian perseroan melanggar ketentuan Pasal 27 UU 5/1999, maka perlu adanya Indikasi terkait dengan pelanggaran Pasal 27 tersebut yang antara lain:

Diantara pelaku usaha memiliki hubungan atau keterkaitan secara finansial/keuangan.

Faktor finansial dapat mendorong pelaku usaha untuk mengembangkan usahanya. Dari beberapa tindakan yang dapat diambil, salah satunya adalah melakukan kepemilikan saham mayoritas pada beberapa perusahaan, yang dapat dilakukan dengan cara membeli atau mengakuisisi, sehingga berdampak pada adanya pengendalian perusahaan-perusahaan tersebut. Tindakan tersebut dapat berdampak menghambat persaingan apabila pemilikan saham mayoritas pada beberapa perusahaan tersebut terjadi pada pasar bersangkutan yang sama.

Pasar bersangkutan yang sama

Pelaku usaha yang mempunyai saham mayoritas di beberapa perusahaan pada pasar bersangkutan yang sama, akan memiliki kecenderungan untuk menguasai atau mengkontrol pasar, dengan kemungkinan menerapkan kebijakan yang sama pada pasar bersangkutan tersebut.

Memegang Posisi dominan.

Posisi dominan adalah dampak dari penguasaan saham mayoritas di beberapa perusahaan. Tidak mungkin pelaku usaha yang memiliki saham kecil pada beberapa perusahaan akan memiliki posisi dominan. 
Penguasaan pangsa pasar tersebut menyebabkan suatu pelaku usaha atau satu kelompok usaha memegang kendali karena posisi dominan yang dimilikinya. Potensi kontrol tersebut menjadi sangat besar apabila pelaku usaha menjadi pemegang posisi dominan dalam penguasaan pangsa pasar.

Pada industri yang terdapat pemain dominan (dominant player) didalamnya, maka kepemilikan silang saham yang terjadi tidak hanya akan berdampak pada peningkatkan konsentrasi dominant player tersebut saja. Peningkatan konsentrasi tersebut memberikan ruang terjadinya market power. Kepemilikan silang saham dari dua PT atau anak perusahaan, apabila digabung menjadi satu dan jumlahnya menguasai lebih $75 \%$ dari pangsa pasar maka kondisi seperti ini jelas merupakan praktek monopoli.

\section{PENUTUP}

\section{Kesimpulan}

Kepemilikan silang saham yang timbul sebagai akibat pengeluaran saham baru saja yang dilarang oleh Undang-Undang Perseroan Terbatas, sedangkan untuk silang saham yang diperoleh dari adanya peralihan karena hukum dan atau jual beli, hibah dan wasiat tidak secara eksplisit dikatakan dilarang, namun dengan konsekuensi hukum bahwa terjadinya kepemilikan silang tidak boleh dibiarkan permanen dan harus dialihkan pada pihak lain dalam jangka waktu 1 (satu) tahun.

Kepemilikan silang saham dikatakan bertentangan dengan UndangUndang Nomor 5 Tahun 1999 Tentang Larangan Praktek Monopoli Dan Persaingan Usaha Tidak Sehat apabila kepemilkan silang saham dari dua Perseroan yang menguasai pasar apabila digabung menjadi satu jumlahnya menguasai lebih $75 \%$ (tujuh puluh lima persen) dari pangsa pasar.

\section{Saran}

Undang-Undang Perseroan Terbatas harus lebih tegas mengatur kepemilikan silang saham dan diperlukan lembaga yang secara teratur mengenai kepemilikan silang saham agar terjadi persaingan usaha yang sehat dan menghindari terjadinya praktek monopoli

\section{DAFTAR PUSTAKA}

Juliana Citra, "Kajian Hukum Tentang Kepemilikan Silang Saham Menurut Undang-Undang Perseroan Terbatas Nomor 40 Tahun 2007", Tesis, Sekolah Pasca Sarjana, Universitas Sumatra Utara, Medan, 2009

Departemen Pendidikan Nasional, Kamus Besar Bahasa Indonesia, Balai Pustaka, Jakarta, 2000

H.Boerhanoedin St.Batuah, dkk., Kamus Istilah Hukum Fockema Andreae Belanda-Indonesia, Binacipta, Bandung, 1983

Departemen Keuangan RI-Badan Pelaksana Pasar Modal, Kamus Khusus Pasar Modal dan Uang, Tanpa Penerbit, Jakarta, 1974

John Downs dan Jordan Elliot Goodman, Kamus Istilah Keuangan dan Investasi, Elex Media Komputindo, Jakarta, 1994

Gunawan Widjaja, Hak Individu dan Kolektif Para Pemegang Saham, Forum Sahabat, Jakarta, 2008

Muria Bonita dan Guntur Putro Jati, "Cermati UU PT Baru, Banyak Aturan Krusial" dalam Rita Tri Agustina, "Tinjauan Yuridis Larangan Kepemilikan Saham Silang (Share Cross Ownership) 
Antar Perusahaan Telekomunikasi

Berdasarkan Undang-Undang

Nomor 5 Tahun 1999 Tentang

Larangan Praktek Monopoli Dan

Persaingan Usaha Tidak Sehat",

Tesis, Fakultas Hukum, Universitas Sebelas Maret, Surakarta, 2008

The Editors of Second College Edition, The American Heritage Dictionary, 2nd ed., Houghton Mifflin Company, Boston, 1982

Maria Cesilia Hapsari, "Analisis Yuridis Terhadap Penerapan Pasal 50 Huruf A Undang-Undang Nomor 5 Tahun 1999 Tentang Larangan Praktek Monopoli Dan Persaingan Usaha Tidak Sehat (Studi Kasus Putusan Mahkamah Agung Nomor 03/K/KPPU/2006)", Tesis, Universitas Indonesia, Fakultas
Hukum, Program Studi Ilmu Hukum, Kekhususan Hukum Ekonomi, Jakarta, Juli 2010

Arie Siswanto, Hukum Persaingan Usaha, Ghalia Indonesia, Jakarta, 2002

Indar Sri Bulan, "Tanggung Jawab Pribadi Pemegang Saham Berdasarkan Kepemilikan Sahamnya Menurut Ketentuan Pasal 27 Undang-Undang Nomor 5 Tahun 1999 Tentang Larangan Praktek Monopoli Dan Persaingan Usaha Tidak Sehat Juncto Undang-Undang Nomor 40 Tahun 2007 Tentang Perseroan Terbatas", Tesis, Fakultas Hukum, Program Studi Magister Kenotariatan, Universitas Indonesia, Depok, Juli 2010 